\section{artelogie}

\section{Artelogie}

Recherche sur les arts, le patrimoine et la littérature de l'Amérique latine

$15 \mid 2020$

Latin American networks: Synchronicities, Contacts and Divergences.

\title{
Réseaux artistiques latino-américains : synchronicités, contacts et divergences.
}

Latin American Networks: Synchronicities, Contacts and Divergences

\section{George F. Flaherty and Andrea Giunta}

\section{(2) OpenEdition \\ Journals}

Electronic version

URL: http://journals.openedition.org/artelogie/4471

DOI: $10.4000 /$ artelogie.4471

ISSN: 2115-6395

Publisher

Association ESCAL

\section{Electronic reference}

George F. Flaherty and Andrea Giunta, "Réseaux artistiques latino-américains : synchronicités, contacts et divergences. », Artelogie [Online], 15 | 2020, Online since 08 April 2020, connection on 06 August 2020. URL : http://journals.openedition.org/artelogie/4471 ; DOI : https://doi.org/10.4000/ artelogie. 4471

This text was automatically generated on 6 August 2020

Association ESCAL 


\title{
Réseaux artistiques latino- américains : synchronicités, contacts et divergences.
}

\author{
Latin American Networks: Synchronicities, Contacts and Divergences
}

\author{
George F. Flaherty and Andrea Giunta
}

\section{Revised by Jane Brodie}

Understanding originality and innovation to be proposals that contribute to the interpretation of change and to the formation of a transnational field of art and visual culture from Latin America, this dossier for Artelogie investigates tensions between the historical avant-gardes of the early twentieth century, both in Latin America and Europe, and the neo avant-gardes that emerged globally between 1960 and 1990, approximately. ${ }^{1}$ The relationship between these vanguards has been fraught by theoretical and methodological difficulties posed by scholarly literatures that have assessed these phenomena, themselves by no means homogenous or coordinated, mostly in terms of derivation and creative exhaustion. This assessment has originated from the so-called centers of the art world and early universalist theories of the avantgarde rather than from their local places of art making and its circulation. These largely Eurocentric claims have foreclosed analysis of the historical significance of key moments in postwar art and their critical and innovative potential in comparative terms. ${ }^{2}$ The reappearance of collage and assemblage, and of grid and monochromatic painting, to name only a few avant-garde techniques, was a self-reflexive return, offering a critique of postwar societies. Neo avant-gardes consciously forged formal and informal networks that linked colleagues and strategies beyond their local scenes or nationalist histories. With this dossier we seek to investigate temporal, spatial, formal, and thematic synchronicities that emerge from both contact and divergence among artworks, artists, critics, curators, and other cultural agents. Through their critical comparison we expect to produce conceptualizations of postwar art history that generate and invert rather than merely add to dominant narratives to date. 
2 Instead of thinking about Latin American art in terms of periphery or decentralization, concepts that are generally used to underscore the differences between modernization processes, avant-gardes, and neo avant-gardes as they took shape in Latin America as opposed to in North America and Europe (think of peripheral modernity or decentralized conceptualism), we will focus on simultaneous processes. Without ignoring relations between international poetics, our concern are specific local formulations, which adopted specific names. ${ }^{3}$ Rather than focus on a Euro-North American history of styles (cubism, surrealism, conceptualism, and all the -isms that order the narrative of what is called "modern art"), we intend, in this dossier, to give visibility to the words used by the groups themselves (MADI, GRAV, Grupo de los Trece) and the networks that connected them, to exhibitions (Prospective 74 and exhibitions of abstract art), to magazines (Arturo, Madí, Concrete Art Invention), and to institutions (such as the Museo de la Solidaridad Salvador Allende).

3 The use of specific terms by no means denies the vocabularies shared by art historians and cultural theorists. Indeed, more specificity and less equivalence of terms and categories goads an interrogation of received wisdom, and as a result we take more care when we build bridges between art scenes and geographic locations. This approach does, however, bring methodological challenges. A researcher may look for an artist or visual idea that traveled across the Americas. Or, if she fails to find a substantial and historically verifiable link between people, concepts, and places, she might look for a more general conceptual affinity. In this scenario, we are working with questions of vision and imagination-whether those of the object of inquiry or those of the researcher. Synchronicity here is a hermeneutics-not a mere footnote or subtext. Despite the risks involved, these leaps of imagination and interpretation, this insistence on transnational and comparative thinking, is what begins to break up capitalistic or colonial logics. It is with these gestures that the networks of art from Latin America become richer, repetitive in the best possible way due to the many possible connections and disjunctures between objects, actors, and cultural processes. ${ }^{4}$

4 This dossier is organized into four sections that propose a comparative analysis of situated cases. The first section, which we title "Utopias between Abstraction and Solidarity," focuses on the utopic aesthetic ideas and institutions that were generated at two junctures. First, the postwar period when, faced with devastation of the very concept of civilization, with the need to reconstruct a ravaged Europe and a world ravaged at the hands of Europe, it was pressing to imagine the world in new ways. The abstract projects articulated in Latin America were central to the formation of an imaginary of the future. The origin of the second context lies in Chile after the 1970 elections, when a socialist government was voted into office. In 1973, a coup d'etat would remove that government. One response to that turn of events was an original and unique initiative: the Museo de la Solidaridad (Museum in Solidarity) with the People of Chile).

5 From specific perspectives, three articles develop the lines of theory that this first section addresses. First, "Geometry and Movement, Latin Americans in the International Art Network" by Cristina Rossi interrogates the emergence, in different contexts, of the abstract and concrete avant-gardes in Latin America, as well as their development from the sixties onward. She analyzes how a Latin American avant-garde network took shape and argues that it was by no means subaltern in relation to European abstraction. These avant-gardes and neo avant-gardes generated 
their own specific exchanges and ideas. The article undertakes a historical review that begins with the launch of Arturo magazine in 1944 and spans into the kinetic neo avantgarde of the late fifties and early sixties. Rossi discusses as well the historical process from which networks and exchanges between artists were formed. Central to her hypothesis is the spread of ideas and relations through trips-the one taken by José Mimó from Argentina to Venezuela in 1947, for example, to exhibit works by Argentine artists such as Méle, Enio Iommi, and Nélida Fedullo. Was that group show or the show of Otero's Las cafeteras (Coffee Pots) that same year responsible for the turn towards abstraction in Venezuela? The presence of Kosice in Paris; the correspondence between Raúl Lozza, on the one hand, and Hans Platschek and Sarandí Cabrera, both of them in Uruguay, on the other; the participation of Argentine abstract artists in publications such as the magazine Joaquim based in Curitiba, in the São Paulo Biennial, in the exhibitions at the Museu da Arte Moderna in Rio de Janeiro and at the Setedelijk Museum in Amsterdam, and their contacts with the Universidad Católica of Valparaíso; the work of Julio Le Parc and the Center of Recherche d'Art Visuel in Paris; Signals and Ailleurs magazines in Europe: these were some of the scenarios for exchange. The genealogies Rossi traces do not neglect transatlantic relations. Her article, rather, gives visibility to shared expectations and to specific ideas materialized through various forms of exchange.

6 Adele Nelson begins her article, "Far from Good Design: Social Responsibility and Waldemar Cordeiro's Early Theory of Form," in the archive, studying the papers of that Italian-born Brazilian artist, critic, and curator. Cordeiro, a champion of Grupo Ruptura, was one of the prime movers of Concrete Art in São Paulo. Nelson finds two documents from 1953 in the same file: a newspaper clipping of an article on Ruptura that Cordeiro wrote and his delegate card for the Congreso Continental de la Cultura organized by Pablo Neruda in Santiago, Chile. This coincidence-or synchronicityleads Nelson to complicate the formerly pat art historical narrative on Cordeiro's thinking about form, especially in relation to his leftist politics and his understanding of the social purpose of abstraction. As Nelson shows, artistic theories rarely develop along geometric lines; their routes are more circuitous. In the late forties, Cordeiro had been a pugnacious purist, calling for an art of formal relations to the exclusion of any other form of art. With time and in conversation with (and contradistinction from) various direct (and indirect) interlocutors in Brazil and abroad, among them artists Almir Mavignier and Max Bill, critics Sérgio Milliet and Mário Pedrosa, and aesthetic theorist Konrad Fielder, Cordeiro's thinking changed. Nelson argues that his conceptualization of abstraction changed through his interest in placing artists at the center of emerging art institutions such as the São Paulo Biennial and the Museu de Arte Moderna in that city; the urban nature of those institutions and the experiences they offered also influenced his abstraction. What Nelson calls the "interpretive paths" of Cordeiro and other artists close to him lead us to the grayer zones of history.

7 An intellectual can draw a network between geographies on the basis of their experience, of their biography. Jacques Leenhard reviews important moments in the life of Brazilian critic Mario Pedrosa, whom he meet during the critic's exile in Paris in the seventies. His article, "Mario Pedrosa, a parcours moderne 1900-1981," follows the critic in Brazil and Chile, where he helped build an international network that linked art and politics. In 1938, he was a member of the Executive Committee of the Fourth International; in the forties, he formed part of a group of artists that conceived a project for a public psychiatric hospital in Rio de Janeiro; in 1949, he wrote his thesis 
De la naturaleza afectiva de las formas (On the Affective Nature of Forms) that, on the basis of phenomenology, addressed the relationship between forms and affects. In 1959, he organized the international congress of the Asociación Internacional de Críticos de Arte (International Association of Art Critics) in Brasilia titled Ciudad Nueva - Síntesis de las Artes (New City - Synthesis of the Arts). For it, he brought together the most celebrated urbanists on the international scene. In 1971, he arrived in Chile as an exile to work at the Institute of Latin American Art History housed at the Universidad de Chile. It was there that he advocated for the creation of a museum of modern art in solidarity with the people of Chile. After the Chilean coup, by which time Pedrosa was in exile in France, he conceived of the Museo de la Resistencia (Resistance Museum). In 1977, he returned to Brazil, where he proposed an innovative structure for the MAM in Rio de Janeiro that would consist of four interlinked sections: the museum of the Indian, the museum of "virgin art" or the art of the unconscious, the museum of black art, and the museum of folk art. At stake was a return to the popular roots of art present in his proposals from the forties and an anthropological understanding of perception with a political agenda. With each initiative and each decision, Pedrosa formed a network of artists and intellectuals

8 The second section of this dossier consists of two articles on the artistic formations that developed around mail art and artists' books, and their relationship to the international circuit. In "Conceptualism in Transit: Horacio Zabala's Maps," Luiza Paladino addresses the networks and contacts that took shape in the early seventies around, on the one hand, two institutions-the Museo de Arte Contemporáneo de la Universidad de São Pablo (MAC USP) and the Centro de Arte y Comunicación (CAyC) de Buenos Aires-and artist Jorge Zabala, on the other. This article not only contributes to a history of exhibitions in Latin America, but also advances in the comparative study of institutional strategies. In their actions, Walter Zanini, director of the MAC USP, and Jorge Glusberg, director of the $\mathrm{CAyC}$, articulated new forms of production and exhibition, as well as artistic concepts. The MAC USP supported intense experimentation and mail art networks that went beyond the logic of the market. The CAyC explored and furthered the relationship between art and technology from a "poor" perspective linked to the vision of Polish theater director Jerzy Grotowski. In 1972, at the Coltejer Biennial, Glusberg proposed the notion of "ideological conceptualism" for Latin America, a concept that Simón Marchan Fiz's adapted and spread widely in his book Del arte del objeto al arte del concepto (From Object Art to Concept Art). This convergence of ideas is addressed through the specific case of Horacio Zabala, particularly his work for Prospective 74, an exhibition organized by Julio Plaza and Walter Zanini. For that show, the artist made a series of world maps intervened with rubber stamps, press clippings, collage, and fire. These interventions questioned established geographies-in the sense of maps of power, among other things-and reflected on censorship and the violation of human rights during dictatorships in Latin America. The precariousness of the means of production and work with found and low-cost materials were critical strategies that tested the relationship between art and politics.

Paulo Silveira's “A Conceptual Definition of the Artist's Book and A New Look at Ulises Carrión's Thinking" begins with an analysis of the actions of Ulises Carrión, an artist, editor, archivist, and bookseller. Born in Mexico, Carrión emigrated to the Netherlands in 1970. Much of his work revolved around the concept of the artist's book. Carrión was mostly active in Europe-more precisely, in Amsterdam-where he 
launched initiatives such as the In-Out Center exhibition space (1972) and Other Books and So bookstore (1975-78), considered the first bookstore dedicated exclusively to artist books. From 1980 until the time of his death in 1989, he worked on Other Books and So Archive. In addition to providing an overview of studies on Ulises Carrión and a chronology of recent exhibitions featuring his work, Silveira analyzes and describes his production. Carrión's practices embody the concept of the network: he was a constant point of reference for the printing of small, unique, unconventional books. Carrión's "The New Art of Making Books" was translated into many languages; it is central to the analysis of what Carrión called workbooks. Along with the translations, Carrión's presentations of his writings in various international settings contributed to placing his practices and his concepts in wider exchanges and networks. Similarly, his archive revolves around an imaginary of small and itinerant tangible forms of artistic creation outside-until recently, at least-the desires of the art market.

The two articles in the third section focus on the networks drawn by cultural diplomacy involving broader geopolitical cultural strategies. Working with the papers of José Gómez Sicre, who served as head curator of the Washington-based Organization of American States (OAS, OEA in Spanish) from 1946 to 1981, Ivonne Pini and María Clara Bernal draw in greater detail, and scrutinize, one of the betterknown figures in the construction of "Latin American Art." Their article, "José Gómez Sicre and his Impact on the Department of Visual Arts, OAS" addresses the anxieties and biases of the Cuban-born cultural administrator, which informed his approach to the cultural diplomacy between the United States and the Western Hemisphere during the Cold War. Above all, Gómez Sicre favored art, especially abstraction, that could be framed in modernist, internationalist, and anti-communist terms. This project was articulated with and against many of his colleagues: Alfred $\mathrm{H}$. Barr, Jr.; Marta Traba; Jorge Romero Brest; Juan Acha; and Fernando Syszlo. Gómez Sicre's aim was to insert art from Latin American into "global" or "universal" art circuits. But as Pini and Bernal make clear, these seemingly cosmopolitan circuits fundamentally reproduced Euro-American political and economic dominance. As with Nelson, the archival details are significant. Gómez Sicre wanted a modern art with a "Latin American accent," as Pini and Bernal note. This turn of phrase betrays his desire for the local, national, or indigenous to be a slight modifier, a minor exoticism for export. In this case, art circuits and critical networks are not paths to true democratization but North American aspirations of hegemony.

Charles Quevedo, in his article "The Brazilian Cultural Mission and the Arte Nuevo Group: Regional Dispute for Cultural Hegemony and Paraguayan Artistic Modernity," offers a narrative about transnational cultural diplomacy that is not unilateral, even if it did emerge out of one nation's strategy to displace the influence of another during the Cold War. Indeed, as Quevedeo argues, such diplomacy was a catalyst for a renewal of Paraguay's artistic scene already underway at the impetus of local actors. Quevedo brings to our attention the Misión Cultural Brasileña, part of a program developed by the Brazilian government to exercise soft power in South America, especially against Argentina, which was a magnet for Paraguayan elites. The mission sponsored travelling exhibitions of Brazilian art and educational and artistic exchanges between the two countries, among other activities. The program was very much a discursive one, including articles published in the Paraguayan press on Brazilian topics. Paraguayan artists and intellectuals were invited to visit their neighbor to the east. Their response to Brazil's strategic internationalism was hardly 
passive. When Brazil finally invited Paraguayan artists to the 1953 São Paulo Biennial, its second iteration, the selection process revealed intergenerational tensions. Members of the artist group Arte Nuevo (Olga Blinder, Lilí del Mónico, and José Laterza Parodi) struck out on its own regionalist course, exhibiting together. As Antonio Gramsci reminds us, there is no hegemony without consent. The regional became a space for emerging Paraguayan artists to inscribe themselves into modernity on their own terms. Quevedo presents a case of simultaneous contact and divergence.

The fourth and final section of this dossier consists of a chapter on contemporary visual practices that connects human rights, memory, and the act of embroidering. Katia Olalde Rico's article "Stitching the Social Fabric against Violence and Oblivion: The Embroidering for Peace and Memory Initiative Revisited through the Lens of Caring Democracy" analyzes a collective and international initiative, in 2011, to embroider handkerchiefs to commemorate the victims of the war on drugs in Mexico. Centered on the notion of the ethics of care, the essay analyzes the technical minutiae of hand embroidering and the bodily posture it entails. It explains how the collective project involved citizens from around the world in Mexico's humanitarian crisis. The potential of the practice of democratic "care with" is particularly poignant in the present context of the pandemic, when words such as "care," "participation," and "networking" take on new meaning as they find new forms of expression.

The articles in this dossier evidence networks that formed a geography different from the one established by art histories based on the repetition of Euro-North American genealogies in other regions. Latin American abstraction toured various cities in Latin America, and in each it found a different place for itself. In the sixties, it settled outside the region, in Paris, as kinetic, urban, and participatory art. It proposed a specific language linked to the critical strategies of the neo avant-garde. Mexican Ulises Carrión's notion of the workbooks spread from Amsterdam, where he lived, to the places he gave lectures and where his challenging texts made an impact. Latin American institutions like MAC USP and CAyC traced intercontinental geographies between clusters and practices that are generally studied separately. The cultural policies that were articulated between Brazil and Paraguay dismantle a classic scheme that assumes power relations to be organized outward from the United States, France, and England to the rest of the world, which is seen as peripheral or decentered. That said, cultural policies were also structured from the north: institutions such as the OAS, led by Gómez Sicre, were functional to a logic of hemispheric power that, from the United States, upheld abstraction-not an obviously political school-as the optimal style for Latin America. What these cases show is that there is not a single history of modern and contemporary art, but many stories. Some of the articles published here reveal that comparison-between different agendas for abstraction, say-shows parallels and simultaneities that question the centrifugal genealogies so often used to order the history of art. The juxtaposition of these particular texts demonstrates to what extent mail art or the artist's book as delicate and non-heroic formats and languages reveals specific ways of understanding the art object.

Finally, the cases discussed arose in the period that spans from the wake of World War II-a period fraught with tensions as attempts were made to find terms with which to further the utopian and constructive projects suspended by the horror of the conflictto the sixties and seventies with the emergence of the neo avant-gardes. Those latter movements no longer occurred exclusively in relation to the European historical avant- 
gardes, but also to the dynamics of the Latin American avant-gardes. This dossier poses the challenge of rethinking art history in terms of alternative networks and conceptualizations.

\section{ENDNOTES}

1. The origin of this dossier is "Grounds for Comparison: Neo-Vanguards and Latin American/U.S. Latino Art, 1960-90," a series of research seminars directed by the dossier's editors between 2013 and 2015 and organized in collaboration with Carmela Jaramillo Jiménez of the Universidad de Bogotá Jorge Tadeo Lozano, Cristina Freire of the Museu de Arte Contemporânea da Universidade de São Paulo, and Inés Katzenstein of the Universidad Torcuato Di Tella. The contributions of Cristina Rossi, Luiza Paladino, Paulo Silveira, Ivonne Pini, María Clara Bernal, Charles Quevedo and Katia Olalde Rico were first presented in these seminars. The articles by Jacques Lenhaard, and Adele Nelson, were selected pursuant to a call for papers circulated in Artelogie, March 2019. We thank the Getty Foundation for its generous support.

2. On the methodological and historiographical problems of synchronous and comparative analysis that must inform any revision of dominant narratives of modern and contemporary art, see Andrea Giunta and George F. Flaherty, "Latin American Art History: An Historiographic Turn," Art in Translation 9, supplement 1 (2017), 121-142. On exhibitions as fields of comparison par excellence, see Andrea Giunta and George F. Flaherty, "Las exhibiciones como campos de comparación/Exhibitions as Fields of Comparison," Caiana: Revista de Historia del Arte y Cultura Visual del Centro Argentino de Investigadores de Arte 11 (2017), 94-109.

3. On the problematization of the notions of periphery and decentralization in relation to theorizing the Latin American avant-gardes and the notion of simultaneous avant-gardes, see Andrea Giunta, Contra el canon. El arte en un mundo sin centro, Buenos Aires, Siglo XXI, 2020.

4. George F. Flaherty, "Nuevas palabras clave: Vocabularios compartidos para redes críticas de historia del arte," unpublished lecture, Centro Nacional de Arte Contemporáneo Cerrillos, Santiago, Chile, April 2019.

\section{ABSTRACTS}

Understanding originality and innovation to be proposals that contribute to the interpretation of change and to the formation of a transnational field of art and visual culture from Latin America, this dossier for Artelogie investigates tensions between the historical avant-gardes of the early twentieth century, both in Latin America and Europe, and the neo avant-gardes that emerged globally between 1960 and 1990, approximately. The relationship between these vanguards has been fraught by theoretical and methodological difficulties posed by scholarly literatures that have assessed these phenomena, themselves by no means homogenous or coordinated, mostly in terms of derivation and creative exhaustion. This assessment has originated from the so-called centers of the art world and early universalist theories of the avant-garde rather than from their local places of art making and its circulation. These largely Eurocentric claims have foreclosed analysis of the historical significance of key moments in postwar art and their critical and innovative potential in comparative terms. The reappearance of collage and assemblage, and of 
grid and monochromatic painting, to name only a few avant-garde techniques, was a selfreflexive return, offering a critique of postwar societies. Neo avant-gardes consciously forged formal and informal networks that linked colleagues and strategies beyond their local scenes or nationalist histories. With this dossier we seek to investigate temporal, spatial, formal, and thematic synchronicities that emerge from both contact and divergence among artworks, artists, critics, curators, and other cultural agents. Through their critical comparison we expect to produce conceptualizations of postwar art history that generate and invert rather than merely add to dominant narratives to date.

Entendiendo la originalidad y la innovación como propuestas que contribuyen a la interpretación del cambio y la formación de un campo transnacional, este número de Artelogie explora las tensiones entre las vanguardias históricas de principios del siglo XX (tanto latinoamericanas como europeas) y las neo-vanguardias que surgieron entre 1960 y 1990, aproximadamente, en el arte latino y latinoamericano. Hasta el presente esta relación ha estado plagada de dificultades teóricas y metodológicas planteadas por literaturas académicas que han evaluado estos fenómenos, que de ninguna manera son homogéneos o coordinados, sobre todo en términos de derivación y agotamiento creativo con respecto a los centros hegemónicos del mundo del arte. Esta perspectiva ha excluido el análisis del significado histórico de los momentos clave en el arte de la posguerra y su potencial crítico e innovador en términos comparativos. La reaparición del collage y el assemblage, y de la pintura abstracta y monocromática, por mencionar solo algunas técnicas vanguardistas, implicó un retorno autorreflexivo que ofreció una crítica de las sociedades de la posguerra. Los artistas de vanguardia forjaron conscientemente redes formales e informales que vincularon artistas y estrategias más allá de sus escenarios locales o historias nacionales. Con el presente dossier buscamos investigar estas sincronicidades que surgen tanto del contacto como de la divergencia. A través de su comparación crítica, esperamos producir conceptualizaciones de la historia del arte de la posguerra que generen e inviertan las denominaciones que ordenan la historia del arte, en lugar de simplemente agregar artistas a las narrativas globales que dominan hasta el presente.

\section{INDEX}

Keywords: ARTE CONCRETO INVENCION, MADI, Groupe de Recherche d'Art Visuel (grav), Groupe Position, $1^{\underline{a}}$ Muestra Internacional “Forma y Espacio", Kinetic Art, Exchange network

Palabras claves: ARTE CONCRETO INVENCION, MADI, Groupe de Recherche d'Art Visuel (grav), Groupe Position - $1^{\underline{a}}$ Muestra Internacional “Forma y Espacio", Kinetic Art, Exchange network

\section{AUTHORS}

\section{GEORGE F. FLAHERTY}

The University of Texas at Austin

\section{ANDREA GIUNTA}

Universidad de Buenos Aires / Conicet / The University of Texas at Austin 